JPT: Jurnal Proteksi Tanaman

(Journal of Plant Protection)

Vol 5 No.1 (2021): $24-33$

ISSN : 2580-0604, Online ISSN: 2621

Website:http://jpt.faperta.unand.ac.id/index.php/jpt

Terakreditasi: Sinta 4

\title{
Pathogenicity and Detection of Phytohormone (Gibberellic Acid and Indole Acetic Acid) Produced by Fusarium spp. that Causes Twisted Disease in Shallot
}

\author{
Pengujian Patogenisitas dan Fitohormon (Asam Giberelat dan Asam Indol Asetat) pada \\ Fusarium spp. yang Menyebabkan Penyakit Moler pada Bawang Merah \\ Ayu Lestiyani ${ }^{1)^{*}}$, Arif Wibowo $^{2)}$, Siti Subandiyah ${ }^{2)}$ \\ ${ }^{1)}$ Agrotechnology Department, Faculty of Agriculture, Universitas Tidar, Indonesia \\ 2)Plant Pest and Disease Science Department, Faculty of Agriculture, Universitas Gadjah Mada, \\ Indonesia \\ E-mail: ayu.lestiyani@untidar.ac.id \\ Diterima: 09 Maret 2021 Disetujui: 22 Juni 2021 Dipublikasi: 30 Juni 2021
}

\begin{abstract}
The twisted disease is one of the essential diseases in shallots caused by Fusarium spp. This study aimed to study pathogenicity and identify Fusarium species isolated from shallot plants with twisted symptoms in Nganjuk and Bantul areas. The Fusarium isolates were identified and then tested for pathogenicity levels and the effect of the hormones $\mathrm{GA}_{3}$ and IAA on shallot symptoms. Molecular identification using NF2 and NF4 successfully identified one isolate of Fusarium oxysporum, three isolates of $F$. acutatum, and three isolates of $F$. solani. Each of these species produces different symptoms. Pathogenicity test showed that all isolates had disease incidence reaching $100 \%$, except isolates of $F$. solani ${ }^{1}$ causing wilt and $F$. solani ${ }^{3}$ causing twisted have the lower disease incidence were $77.8 \%$ and $77.7 \%$, respectively. The investigation caused twisted shallot related to different symptoms was tested using the Thin Layer Chromatography (TLC) method. The result indicates that all isolates did not find IAA hormone. In contrast, the hormone $\mathrm{GA}_{3}$ was found in $F$. solani ${ }^{2}$ and $F$. solani ${ }^{3}$ isolates, caused bulb rot and twisted disease, respectively. Detection of IAA, $\mathrm{GA}_{3}$, and other hormones in shallot plants showed different symptoms should be studied further.

Keywords: F. acutatum, F. oxysporum, F. solani, GA 3 , IAA, Shallot, Thin Layer Chromatography, Twisted Disease

\section{ABSTRAK}

Penyakit moler merupakan salah satu penyakit penting pada pertanaman bawang merah yang disebabkan oleh Fusarium spp. Penelitian ini bertujuan mengidentifikasi spesies Fusarium yang diisolasi dari tanaman bawang merah yang bergejala moler di daerah Nganjuk dan Bantul. Isolat-isolat Fusarium yang diperoleh diidentifikasi selanjutnya diuji tingkat patogenisitasnya, serta mengetahui pengaruh hormon $\mathrm{GA}_{3}$ dan IAA terhadap gejala yang timbul pada bawang merah. Hasil identifikasi molekuler menggunakan primer NF2 dan NF4 diperoleh berturut-turut 1 isolat Fusarium oxysporum, 3 isolat $F$. acutatum dan 3 isolat $F$. solani. Setiap spesies tersebut
\end{abstract}


menghasilkan gejala yang berbeda. Uji patogenisitas menunjukkan bahwa semua isolat memiliki patogenisitas yang tinggi mencapai $100 \%$, kecuali isolat $F$. solani ${ }^{1}$ penyebab penyakit layu dan $F$. solani ${ }^{3}$ penyebab penyakit moler memiliki kejadian penyakit yang lebih rendah berturut-turut yaitu $77,8 \%$ dan $77,7 \%$. Semua isolat tidak memproduksi hormon IAA. Sedangkan hormon $\mathrm{GA}_{3}$ ditemukan pada isolat $\mathrm{F}$. solani ${ }^{2}$ yang menyebabkan busuk umbi dan $\mathrm{F}$. solani ${ }^{3}$ yang menyebabkan gejala moler. Deteksi lanjut pada hormon $\mathrm{GA}_{3}$ dan IAA serta hormon-hormon lain yang kemungkinan menyebabkan gejala pada bawang merah, perlu dikaji lebih lanjut.

Kata kunci: Bawang Merah, F. acutatum, F. oxysporum, F. solani, GA 3 , IAA, Kromatografi Lapis Tipis, Penyakit Moler

\section{INTRODUCTION}

Shallot (Allium cepa L. Var. Agregatum (L.)) is a type of Alliaceae bulbous plant widely cultivated globally, especially in Asia (Elizani and Sulistyaningsih, 2019). The twisted disease is one of the most critical diseases becoming a problem in shallots (Triwidodo et al., 1998). The leaf of shallot symptoms was pale green and curving (Lestiyani et al., 2016). According to Ebenebe (1980), the twisted disease was first reported near Zaria, northern Nigeria, in 1969. In 1980, this disease had been considered a severe problem in the north of Nigeria, with yield losses up to $50-100 \%$. The same situation occurred in the Kalpitiya Peninsula, the north-western Province of Sri Lanka, with yield losses up to $20-30 \%$. This disease originated in Indonesia and was initially classified as a minor disease in 1977. The incidence and severity of the disease have increased every year (Triwidodo et al., 1998). The twisted disease has become a primary disease in various shallot production areas in Indonesia (Wiyono, 2007; Wiyatiningsih et al., 2010).

Previous studies have explained that the twisted disease of shallot could be caused by Fusarium oxysporum, F. solani, and $F$. acutatum. However, each species has its role in causing twisted disease, i.e., $F$. solani and $F$. acutatum causes symptoms of shallot wilting; bulb rot is caused by F. solani, $F$. acutatum or F. oxysporum. In contrast, the twisted symptoms are caused by F. solani or F. acutatum (Lestiyani et al., 2016). Meanwhile, Patil et al., 2018 stated that inoculated onion seedlings with Colletotrichum gloeosporioides, F. oxysporum, and Meloidogyne sp. create twisted disease symptoms. It was supported by the application of Gibberellic Acid $\left(G_{3}\right)$ or Indole acetic acid (IAA), and a combination of onion seedling revealed the appearance of twisting symptoms.

At the same time, pathogens can stimulate growth hormones and form hormones or inhibit the plant production of growth regulators or growth inhibitors. Whatever the mechanism of action, pathogens frequently cause an imbalance in the plant hormonal system and cause abnormal growth responses incompatible with healthy development (Agrios, 2005). More IAA has been detected in diseased plants, such as in hyperplasia (Semangun, 2006). The increase in IAA levels was caused by reduced IAA breakdown due to inhibition of the IAA-oxidase enzyme activity. As in Pseudomonas syringae, which also produces auxin, it will change the biology of the host auxin during infection so that auxin levels in plants increase (Marois et al., 2002). 
In comparison, gibberellins have pronounced growth-promoting properties. They promote flowering, stem and root elongation, and fruit growth in dwarf varieties and hasten their stretching to regular sizes. Gibberellins appear to activate previously "turned off" genes. No difference in gibberellin content has been reported between healthy and virus- or mollicuteinfected plants. Spraying diseased plants with gibberellin alleviates some of the symptoms caused by these pathogens (Agrios, 2005). For example, After treatment with gibberellin, the stunting of corn plants infected with corn stunt spiroplasma was reversed (Nault, 1980).

Based on the data above, there is no clear information on the twists involved in the twisted disease of shallots. This study aims to determine whether Fusarium spp. resulted from pathogenicity tests that show different symptoms can produce hormones such as IAA and $G_{3}$; these have wilt, bulb rot, and twisted symptom. This research using Thin Layer Chromatography (TLC), the easiest hormone testing method can be for quantitative growth hormone testing.

\section{METHODOLOGY}

This research was conducted at the Clinical Plant Disease Laboratory, Department of plant protection, Faculty of Agriculture, Universitas Gadjah Mada. This research had done in January-July 2018.

\section{Fungal Identification and Pathogenicity test}

Shallot plants with twisted disease symptoms from the field in Bantul (Yogyakarta) and Nganjuk (East Java) were pulled from the soil, placed in a plastic bag, and transported to the laboratory for fungal isolation. The bulb from twisted disease symptoms was washed, sterilized with $70 \%$ ethanol before cut into small pieces, and placed directly on Potato Dextrose Agar (PDA) medium. The CTAB (cetyltrimethylammonium bromide) method was used to extract fungal DNA. IGS primer 5'CTGAACGCCTCTAAGTCAGA-3' (NF2) and 5'CCTGCGGACGCTCAAAAACTT-3' (NF4) (Chen et al., 2009) were used to amplify fungal DNA. PCR was carried out on 20- $\mu$ l of the reaction mixture that contained $10-\mathrm{pmol}$ of each primer, $10-\mu l$ of Quick taqTM HS dye Mix (Nippon gene), and $80 \mathrm{ng}$ of template DNA. The thermocycler program began with initial denaturation for 2 minutes at $94^{\circ} \mathrm{C}$, followed by 29 cycles of denaturation for 30 seconds at $94^{\circ} \mathrm{C}$, annealing for 30 seconds at $55^{\circ} \mathrm{C}$, and extension for 30 seconds at $68^{\circ} \mathrm{C}$. Electrophoresis on $1.2 \%$ agarose gel separated amplicons, which were stained with ethidium bromide ( $\mathrm{EtBr}$ ) (Lestiyani et al., 2014).

Fusarium spp. that identified pathogenicity testing is performed to determine the disease incidence and visible symptoms. Shallot bulbs in good condition were disinfected with $0.1 \% \mathrm{NaOCl}$ for 30 minutes and rinsed with sterile water, and dried. The dried seeds were soaked in conidia suspension of $10^{6}$ conidia/mL density for 1 hour (Dissanayake et al., 2009). Bulbs were planted in plastic pots filled (3 blubs/pot) with sterile soil that has been incubated in glasshouse condition at a temperature of 28$32^{\circ} \mathrm{C}$ for four weeks and observed every week. Disease incidence was calculated using the formula:

$$
\begin{aligned}
& \text { DI }=\frac{a}{b} \times 100 \% \\
& D I=\text { disease incidence } \\
& A=\text { number of disease plants } \\
& b=\text { total number of plants }
\end{aligned}
$$

Hormone Analysis of IAA and $\mathrm{GA}_{3}$

Each of the Fusarium spp. isolates were grown at $250 \mathrm{~mL}$ of Potato Dextrose Broth for seven days at room temperature. Filtrate 
culture was filtered by Whatman paper no. 42. The $\mathrm{pH}$ of the filtrate was adjusted to $2.5-$ 3.0 , with the addition of $0.1 \mathrm{~N} \mathrm{HCl}$ or $\mathrm{KOH}$ (Bhalla et al., 2009). Ethyl acetate was used for solvent extraction. Filtrate culture was extracted by adding ethyl acetate as much as the filtrate culture $(250 \mathrm{~mL})$ with a separating funnel. The upper organic phase was separated and dried over anhydrous sodium sulfate. The evaporation was then performed on a rotary vacuum evaporator at $40^{\circ} \mathrm{C}, 30 \mathrm{rpm}$. The resulting residue was dissolved with acetonitrile and stored for TLC analysis (Rachev et al., 1993).

TLC plate type 60F 254 (Merck) was run with an eluent consisting of benzene: $n$ butanol: acetic acid (6:3:1) to the $\mathrm{GA}_{3}$ test. The resulting spot can be visualized at UV (254 nm) after spraying with ethanol: concentrated sulfuric acid (95: 5) (Bhalla et al., 2009). IAA testing used eluents consisting of isopropanol: ammonia: water (10: 1: 1) and sprayed with $3 \% \mathrm{H}_{2} \mathrm{SO}_{4}$ in methanol +50 mg $\mathrm{FeCl}_{3}$ and heated $80^{\circ} \mathrm{C}$ for 10 minutes (Hasan, 2002).

Qualitative analysis was compared with standards that were dissolved using the same solvent as the sample compound. Samples with the same value of the retention factor (Rf) can be determined to be identical to the standard. $\mathrm{Rf}$ was calculated using the formula distance traveled by sample/ distance traveled by solvent (Fessenden et al., 2001).

\section{RESULTS}

\section{Fungal Isolation and Identification}

Shallots displayed typical symptoms of twisted disease with shallot leaf shown pale green and curving in the field survey (Figure 1). The isolation results from various sources obtained seven isolates with different Fusarium spp, then identified based on the molecular method, as shown in Table 1.

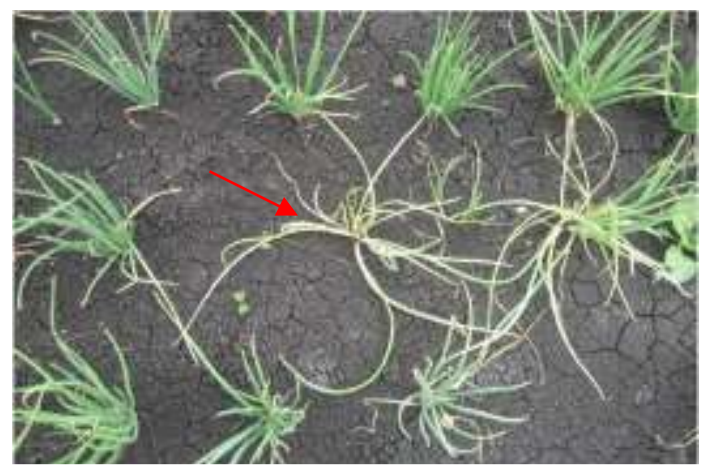

Figure 1. Symptom of twisted disease on shallot

Pathogenicity tests revealed that seven isolates of Fusarium spp. were capable of causing various disease symptoms on shallot. Specifically, wilting caused by $F$. acutatum or $F$. solani, twisted caused by $F$. solani or F. acutatum, and bulb rot caused by $F$. acutatum or $F$. sonali or F. oxysporum. Another result from the pathogenicity test showed that $F$. solani causing wilt and $F$. solani causing twisted have the lower disease incidence were $77.8 \%$ and $77.7 \%$, respectively (Table 1 ).

Wilting on shallots causes the leaves to wilt, turn yellow, and then dry. Bulb rot symptoms were nearly identical to wilting symptoms; tubers were smaller and more rotten than wilting symptom, also turn yellow and wilt faster than shallots with the wilting symptom. Shallots with twisted symptoms have yellowed and twisted leaves (Figure 2).

\section{Hormone analysis of IAA and $\mathrm{GA}_{3}$}

The result of TLC testing showed that from 7 isolates, only two isolates ( $F$. solani ${ }^{2}$, and $F$. solani ${ }^{3}$ ) confirmed $\mathrm{GA}_{3}$ with an $\mathrm{Rf}$ value of 0.73 , wherein bands of light brown colour were observed on the TLC plates (Figure 2A). In contrast, none isolates confirmed IAA ( $R f=0.85$ ) (Figure $2 B$ ). 
Table 1. List of isolate and symptom that caused Fusarium spp.

\begin{tabular}{|c|c|c|c|}
\hline Species & Location & Symptom & Disease incidence (\%) \\
\hline F. acutatum ${ }^{1}$ & Bantul & Wilt & 100 \\
\hline F. solani ${ }^{1}$ & Nganjuk & Wilt & 77.8 \\
\hline F. oxysporum ${ }^{1}$ & Bantul & Bulb Rot & 100 \\
\hline F. acutatum ${ }^{2}$ & Bantul & Bulb Rot & 100 \\
\hline F. solani ${ }^{2}$ & Nganjuk & Bulb Rot & 100 \\
\hline F. solani ${ }^{3}$ & Bantul & Twisted & 77.7 \\
\hline F. acutatum ${ }^{3}$ & Nganjuk & Twisted & 100 \\
\hline
\end{tabular}

Note. ${ }^{1,2},{ }^{3}$ showed isolate number

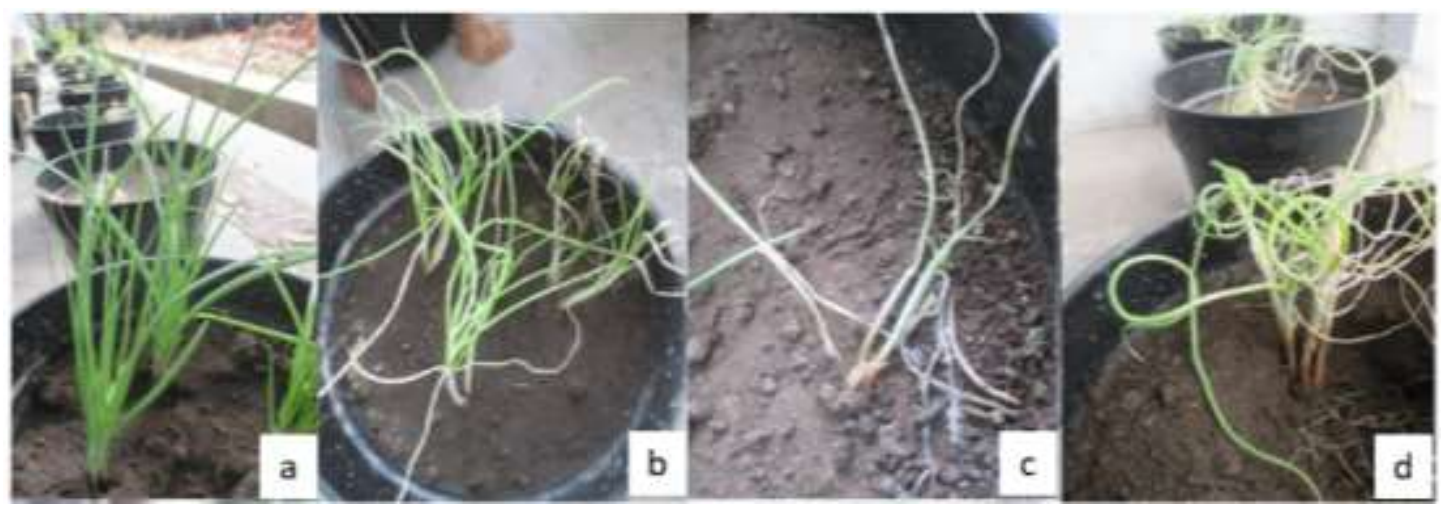

Figure 2. Fusarium spp. caused disease symptoms on shallot: a) healthy shallot; $b$ ) wilting; c) bulb rot; d) twisted disease

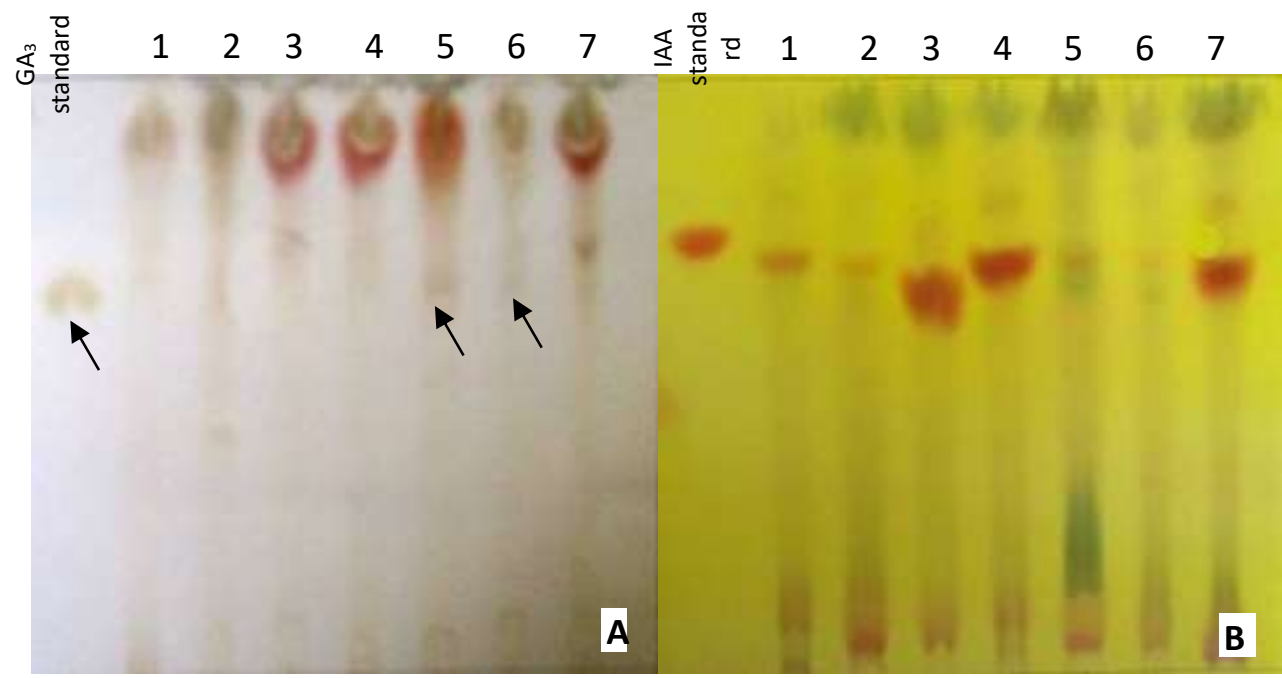

Figure 3. Hormone test in Fusarium spp. by TLC method: A) GA $\mathrm{A}_{3}$ testing; B) IAA testing; 1) $F$. acutatum $^{1}$; 2) F. solani ${ }^{1}$; 3) F. oxysporum ${ }^{1}$; 4) F. acutatum ${ }^{2}$; 5) F. solani ${ }^{2}$; 6) F. solani ; 7) F. acutatum $^{3}$ 


\section{DISCUSSION}

Fusarium spp. has various pathogenicities. Inoculation of Fusarium spp. to host plant is a simple method for determining the pathogenic or nonpathogenic. Strains that do not cause symptoms in plants are considered nonpathogenic for that plant (Tjamos et al., 1992).

Pathogenicity of $F$. oxysporum f. sp. cepae caused root rot and has become a disease in garlic, onions and leeks have done with much research. F. oxysporum f. sp. cepae invade plants through the roots. The development of this disease starts from necrosis on the basal plate, death of old leaves and rot on the inside of the tuber (Hitch et al., 2005). Two other species, F. acutatum and $F$. solani, are less well known for causing disease, but (Kalman et al., 2020) found that $F$. acutatum can cause bulb rot in red onions, and (Boehnke et al., 2015) said that $F$. solani is causing bulb rot in onions. The same species of these were also found in this study.

Seven Fusarium isolates from this study are known to infect plants and cause different symptoms. Wilting caused by $F$. acutatum or $F$. solani, twisted caused by $F$. solani or F. acutatum, and bulb rot caused by F. acutatum or F. sonali or F. oxysporum. The data needs investigating further. The statement was supported by Carrieri et al. (2013) studied that identified the causative agent of pink rot of onion roots and onion bulbs that primarily isolated three fungi: Fusarium proliferatum, Fusarium trincticum, and Pyrenochaeta terresteris. When combined, all Fusarium species will affect the high severity disease; for example, Fusarium Head Blight (FHB) disease affected mycotoxin production. Inoculation using one species, $F$. graminearum, or combining $F$. graminearum with other species produces the highest infection (Ghahderijani, 2008).

Phytohormone was suspected of playing a role in the symptom of the disease. The result of this study was two isolates confirmed $\mathrm{GA}_{3}$ were $F$. solani ${ }^{2}$, and $F$. solani ${ }^{3}$ caused bulb rot and twisted disease, respectively. This result suggests that $F$. solani caused twisted disease is affected by $\mathrm{GA}_{3}$. Previous research was done (Bhalla et al., 2009; Seo et al., 2012' considered that $F$. solani could produce $\mathrm{GA}_{3}$. In the other study, the essential role of $\mathrm{GA}_{3}$ in plant growth is an elongation cell of the stem, roots, flower, and fruit (Achard and Genschik, 2009; Davière and Achard, 2013; Hedden and Sponsel, 2015). However, $\mathrm{GA}_{3}$ can induce the disease as though Bakanae (Matic et al., 2017) induced by Giberella fujikuroi (Desjardins et al., 2000; Hedden and Sponsel, 2015; Sulyanti, 2017; Salazar-Cerezo et al., 2018). G. fujikuroi secreting $\mathrm{GA}_{3}$, which made symptoms in seedlings appear to be taller, more slender, and slightly chlorotic (Cen et al., 2020). That statement is similar to Wiyatiningsih et al. (2010) about the characteristic twisted disease of shallots showing a longer pseudostem and curved leaves dan chlorotic. A possibility that twisted disease is affected by $\mathrm{GA}_{3}$ in that needed advanced technology to analyze it. However, $\mathrm{GA}_{3}$ was also detected on rot symptom, it has not yet been found that $\mathrm{GA}_{3}$ caused it, and further research is needed.

IAA may also act synergistically, such as elongation, similar to that caused by $\mathrm{GA}_{3}$ (Agrios, 2005). Furthermore, IAA regulates plant growth and development of differentiation, tropism, senescence, and flowering (Li et al., 2015). IAA was detected more on plants diseased caused pathogen inducing IAA to produce gall (Fu and Wang, 2011; Denancé et al., 2013; Semangun, 2006), such as clubroot caused Plasmo- 
diophora brassicae (Tian et al., 2019) and smut on maize caused Ustilago maydis (Aydo et al., 2015). Other examples are gall-caused Agrobacterium tumefaciens (Borges et al., 2019), late blight caused Phytophthora infestans (Saville et al., 2016), Fusarium wilt of bananas caused $F$. oxysporum f.sp. cubense (Di et al., 2016), and Fusarium head blight caused F. Graminearum (Yang et al., 2013). The other function, IAA, can reduce germination of Fusarium sp. at the tomato and barley (Sharaf and Farrag, 2004; Petti et al., 2012; Raffi et al., 2017).

In the other study, Ongoagwanit (1991) detected the increase of IAA on onion after $F$. oxysporum induce as a cause of twisted disease. Patil et al. (2018) showed abnormal elongation of the onion plant after IAA and $\mathrm{GA}_{3}$ spraying but did not show any pathogen structure. The statement contrast with this research that IAA was not found in all isolates. Meanwhile, the mechanism of the IAA is not well understood in this study.

\section{CONCLUSION}

Three Fusarium spp. were identified, i.e., F. solani, F. acutatum or F. oxysporum. Wilting, bulb rot, and twisted disease are three classified symptoms of shallot. Wilt symptom on shallot caused by $F$. solani and $F$. acutatum, bulb rot by $F$. solani, $F$. acutatum or $F$. oxysporum, and twisted disease by $F$. solani or F. acutatum. F. solani produced the $\mathrm{GA}_{3}$ hormone at $F$. solani ${ }^{2}$ and F. solani ${ }^{3}$ isolate, while all isolates testing did not produce IAA hormone. The role of the hormone in the symptoms is unclear. Fusarium spp. does not produce the hormone required to cause a more severe infection. However, these assays were successful in identifying the cause of twisted disease in shallot and Fusarium spp. identified as the disease causal agents in this country region. The pathogenicity assays were also helpful in determining the various symptoms caused by each Fusarium spp. The findings of the study are an essential step toward developing a disease-prevention program.

\section{ACKNOWLEDGEMENT}

The authors wish to thank the Australian Centre for International Agricultural Research No. HORT/2009/056 to fund this research.

\section{REFERENCE}

Achard P, and P Genschik. 2009. Releasing the brakes of plant growth: How GAs shutdown della proteins. Journal of Experimental Botany 60(4):10851092.

Agrios G. 2005. Plant Pathology. 5th ed. Academic Press. New York, USA.

Aydo M, ĞDU Nuh, and B Yüksel. 2015. Effect on Yield Losses on Maize (Zea mays L.) Caused by Smut Disease (Ustilago maydis (DC) Corda). Journal of Turkish Phytopathology 44(1):23-30.

Bari R, and JDG Jones. 2009. Role of plant hormones in plant defense responses. Plant Molecular Biology 69(4):473488.

Bhalla K, SB Singh, and R Agarwal. 2009. Quantitative determination of gibberellins by high performance liquid chromatography from various gibberellins producing Fusarium strains. Environmental Monitoring and Assessment 167(1-4):515-520.

Boehnke B, P Karlovsky, K Pfohl, A Gamliel, Y Isack, and HW Dehne. 2015. Identification of Different Fusarium spp. in Allium spp. in Germany. Communication in Agricultural and Applied Biological Sciences 80(3):453463.

Borges RCF, M Rossato, GMR Albuquerque, 
MA Ferreira, ACM Brasileiro, MEN Fonseca, and LS Boiteux. 2019. Crown gall caused by Agrobacterium tumefaciens species complex: a novel nursery disease of Tectona grandis in Brazil. Journal Plant Pathology 101(2):445.

Carrieri R, F Raimo, A Pentangelo, and E Lahoz. 2013. Fusarium proliferatum and Fusarium tricinctum as causal agents of pink rot of onion bulbs and the effect of soil solarization combined with compost amendment in controlling their infections in field. Crop Protection 43:31-37.

Cen Y, J Lin, Y Wang, J Wang, and Z Liu. 2020. The Gibberellin Producer Fusarium fujikuroi : Methods and Technologies in the Current Toolkit. Frontiers in Bioengineering and Biotechnology 8(3):232.

Chen J, M Ge, J Dousa, and G Gendt. 2009. Evaluation of EPOS-RT for real-time deformation monitoring. Journal of Global Positioning Systems 8(1):1-5.

Davière JM, and P Achard. 2013. Gibberellin signaling in plants. Development 140(6):1147-1151.

Denancé N, A Sánchez-Vallet, D Goffner, and A Molina. 2013. Disease resistance or growth: The role of plant hormones in balancing immune responses and fitness costs. Frontiers in Plant Science $4(5): 1-12$.

Di X, FLW Takken, and N Tintor. 2016. How phytohormones shape interactions between plants and the soil-borne fungus Fusarium oxysporum. Frontiers in Plant Science 7(2):1-9.

Dissanayake M, R Kashima, and ESS Tanaka. 2009. Pathogenic variation and molecular characterization of Fusarium species isolated from wilted Welsh onion in Japan. Journal of
General Plant Pathology 75:37-45.

Ebenebe AC. 1980. Onion Twister Disease caused by Glomerella cingulata in Northern Nigeria. Plant Disease 64:1030-1032.

Elizani P, and E Sulistyaningsih. 2019. The Correlation and Regression Analysis of The Growth and Physiological Parameters: How Paclobutrazol Increases Bulb Yield on Three Cultivars of True Shallot Seed. Journal of Sustainable Agriculture 34(2):128-139.

Fessenden RJ, JS Fessenden, and $\mathrm{P}$ Feist. 2001. Organic Laboratory Techniques. Brooks/Cole Thomson Leaning. Canada.

Flors V, J Ton, R Van Doorn, G Jakab, P GarcíaAgustín, and B Mauch-Mani. 2008. Interplay between JA, SA and $A B A$ signaling during basal and induced resistance against Pseudomonas syringae and Alternaria brassicicola. Plant Journal 54(1):81-92.

Fu J, and S Wang. 2011. Insights into auxin signaling in plant-pathogen interactions. Frontiers in Plant Science 2(11):1-7.

Ghahderijani M. 2008. Microbiological and molecular assessment of interactions among the major Fusarium head blight pathogens on wheat ears. [Dissertation]. Institut für Nutzpflan zenwissenschaften und Ressourcen schutz. Iran.

Hasan HAH. 2002. Gibberellin and auxinindole production by plant root-fungi and their biosynthesis under salinitycalcium interaction. Acta Microbiolgica et Immunologica Hungarica 48(3):101106.

Hedden P, and V Sponsel. 2015. A Century of Gibberellin Research. Journal of Plant Growth Regulation 34(4):740-760.

Hitch CJ, EA Oxspring, Wicks, T J, and Hall BH. 
2005. Control of Fusarium Foot Rot in Leeks. South Australian Research and Development Institute. Adelaide.

Kalman B, D Abraham, S Graph, R Perl-treves, YM Harel, and O Degani. 2020. Isolation and Identification of Fusarium spp., the Causal Agents of Onion (Allium cepa) Basal Rot in Northeastern Israel. Biology 9:69.

Lestiyani A, Wibowo A, and Subandiyah S. 2014. Uji metode inokulasi pada bawang merah dengan Fusarium spp. In: Seminar Nasional Dies Natalis Faperta UGM ke-68. Pengembangan dan Pemanfaatan IPTEKS untuk Kedaulatan Pangan Universitas Gadjah Mada, Yogyakarta, 27 September 2014.

Lestiyani A, A Wibowo, S Subandiyah, C Gambley S, Ito, and S Harper. 2016. Identification of Fusarium spp., the causal agent of twisted disease of shallot. Acta Horticultura 1128:155160.

Li W, L Xu, J Wu, L Ma, M Liu, J Jiao, H Li, and F Hu. 2015. Effects of Indole-3-Acetic Acid (IAA), a Plant Hormone, on the Ryegrass Yield and the Removal of Fluoranthene from Soil. International Journal of Phytoremediation 17(5):422-428.

Marois EG, A Van den, and U Bonas. 2002. The Xanthomonas thype III effector protein AvrBs3 modulates plant gene expression and induces cell hypertrophy in the susceptible host. Molecular Plant Microbe Interaction 15:637-646.

Matic S, ML Gullino, and D Spadaro. 2017. The puzzle of bakanae disease through interactions between Fusarium fujikuroi and rice. Frontiers in Bioscience - Elite 9(2):346-357.

Mitter N, AC Srivastava, Renu, S Ahamad, AK
Sarbhoy, and DK Argawal. 2001. Characterization of gibberellin producing strains of Fusarium moniliforme based on DNA polymorphism. Mycopathologia 153(4):187-193.

Nault L. 1980. Maize Bushy Stunt and Corn Stunt: A comparison of Disease Symptoms, Pathogen Host Ranges, and Vectors. Phytopathology 70:659-662.

Omojasola PF, and DO Adejoro. 2018. Gibberellic Acid Production by Fusarium moniliforme and Aspergillus niger Using Submerged Fermentation of Banana Peel. Notulae Scientia Biologicae 10(1):60-67.

Ongoagwanit S. 1991. Onion twister disease caused by Colletotrichum gloeosporioides (Penz.) Sacc. [Thesis]. Kasetsart University. Bangkok, Thailand.

Patil S, VB Nargund, K Hariprasad, G Hegde, S Lingaraju, and VI Benagi. 2018. Etiology of Twister Disease Complex in Onion. International Journal of Current Microbiology and Applied Science 7(12):3644-3657.

Petti C, K Reiber, SS Ali, M Berney, and FM Doohan. 2012. Auxin as a player in the biocontrol of Fusarium head blight disease of barley and its potential as a disease control agent. Plant Biology 12(1):1.

Rachev, RCH, R Pavlova-Rouseva, and SV Bojkova VKG. 1993. Isolation of Gibberellic Acid Produced by Fusarium Moniliforme. Journal of Natural Products 56(7):1168-1170.

Raffi A, BIN Junaidi, and MH Bolhassan. 2017. Screening of Indole-3-Acetic Acid ( IAA ) Productions by Endophytic Fusarium oxysporum Isolated from Phyllanthus niruri. Borneo Journal of Resources Science and Technology 7(1):56-59.

Saville AC, MD Martin, and JB Ristaino. 2016. Historic late blight outbreaks caused by 
a widespread dominant lineage of Phytophthora infestans (Mont.) de Bary. PLoS One 11(12):1-22.

Semangun H. 2006. Pengantar Ilmu Penyakit Tumbuhan. Yogyakarta: UGM Press.

Seo Y, Y-H You, H Yoon, S-M Kang, H Kim, M Kim, C Kim, I-J Lee, and J-G Kim. 2012. Gibberellin A 4 Producted by Fusarium solani Isolated from the Roots of Suaeda japonica Makino. Journal of Life Science 22(12):1718-1723.

Sharaf EF, and AA Farrag. 2004. Induced resistance in tomato plants by IAA against Fusarium oxysporum lycopersici. Polish Journal of Microbiology 53(2):111-116.

Sulyanti E. 2017. Respon Beberapa Varietas Padi Terhadap Serangan Fusarium fujikuroi Penyebab Penyakit Bakanae. Journal Proteksi Tanaman 1(1):18-23.

Tian X, Wang D, Mao Z, Pan L, Liao J, and Cai Z. 2019. Infection of Plasmodiophora brassicae changes the fungal endophyte community of tumourous stem mustard roots as revealed by high-throughput sequencing and culture-dependent methods. PLoS One 14(6):1-15.

Tjamos E, R Cook, and G Papavizas. 1992.
Biological Control of Plant Diseases. Plenum Press. New York, USA.

Triwidodo HTS, D Yuliani, Prijono, and S Wiyono. 1998. Pengembangan Teknologi dan Pemasyarakatan PHT Bawang Merah. Institut Pertanian Bogor Press, Bogor.

Wiyatiningsih S, A Wibowo, and E Triwahyu. 2010. Karakter ketahanan 6 kultivar bawang merah terhadap infeksi Fusarium oxysporum f.sp. cepae penyebab penyakit moler. in: Seminar Hasil Penelitian Dan Pengabdian Kepada Masyarakat Yang Didanai DP2M DIKTI, RISTEK, KKP3T, KPDT, PEMDA dan UPNVJ. Surabaya, 15-16 Desember 2010.

Wiyono S. 2007. Climate change and pests and diseases explosion. Kheti Foundation, Jakarta.

Yang F, S Jacobsen, HJL Jørgensen, DB Collinge, B Svensson, and C Finnie. 2013. Fusarium graminearum and its interactions with cereal heads: Studies in the proteomics era. Frontiers in Plant Science 4(2):1-8. 